\title{
Evaluating Sheath Blight Resistance in Rice Using Detached Tiller and Field Screening Methods
}

\author{
Bedanand Chaudhary \\ Regional Agricultural Research Station, Tarhara, Nepal
}

Email: bedanand.chy@gmail.com

Received April 2015; Revised June 2015; Accepted July 2015

Scientific Editors: BK Joshi, TB Gurung

Copyright (C) 2015 NARC. Permits unrestricted use, distribution, and reproduction in any medium, provided the original work is properly cited

\begin{abstract}
In present study physical resistance test on 12 rice varieties against sheath blight (ShB) caused by Rhizoctonia solani was examined. A detached tiller test was used to measure components of ShB physiological resistance at Regional Agricultural Research Station (RARS), Tarahara, Nepal. The varieties were evaluated in a randomized complete block design (RCBD) with 3 replications in year 2010-12. A sclerotium was inserted below the leaf collar of individual tillers maintained in tubes filled with water. Only the 56-day old susceptible plants were inoculated. After 7 days of inoculation, number of lesions, dead leaves, vertical sheath colonization and disease severity were measured. In 2011, field experiments were conducted with three replications to address morphological resistance in 28 rice genotypes. Disease incidence was recorded on 14,21 and 28 days after inoculation. The number of dead leaves differed only numerically while disease variables significantly $(P=0.004)$ varied among varieties. The other variables were highly correlated with each other. Cluster analysis of variables formed three varietal groups; Sabitri with lowest, and Jasmine-85 and Betichikon having highest values. Rice genotypes differed significantly $(P=0.05)$ for disease incidence and area Under Disease Progress Curve (AUDPC). Tetep and IAC-165 had the lowest and highest terminal disease incidences and AUDPC, respectively. Sabitri, MTU-1010 and IR-26 recorded lower AUDPC values. Hence, Tetep and Sabitri could be used as donors in hybridization and their plant morphology could be considered as selection guide for improving ShB resistance in rice.
\end{abstract}

Key words: Detached tiller, field screening, morphological, physiological resistance and sheath blight

\section{सारांश}

Rhizoctonia solani नामक ढुंसि बाट धानमा लाग्ने पातेफेद डढुवा रोगको अवरोधकताको अध्ययन गरियो । दैहिक (Physiological) अवरोधक क्षमता मापन गर्नको लागि धानको सरामा सन २०१० मा १२ वटा विभिन्न धानका जातहरु समावेश गरि क्षेत्रीय कृषि अनुसन्धान केन्द्र, तरहरामा स्थलगत परीक्षण गरिएको थियो। पानी भरिएको ट्यूवको सहाराले धानको प्रत्येक छुट्टाहुट्टै सराको पात र डाँठ को बीचमा Sclerotium घुसारेर रोग सारिएको थियो । यो परिक्षण रैन्डमाईज क्मपलीट ब्लक डीजाईनका आधारमा तीनवटा रेप्लीकेशन राखि संचालन गरिएको थियो। रोगका जीवाणु सारेको $७$ दिन पछि, रोगका दागहरु, तीव्रता, मरेका पात र डढेका फेदको लम्बाई मापन गरिएको थियो। Morphological अवरोधक गुण मापन गर्नको लागि २६ वटा धानका जातहरु लाई पनि रैन्डमाईज क्मपलीट ब्लक डीजाईनका आधारमा सन् २०११ मा तीन रेप्लिकेशनमा परीक्षण संचालन गरिएको थियो। उक्त परीक्षणमा रोग संवेदनशील धानबालीमा जीवाणु सार्ने काम भएको थियो। रोगका जीवाणु सारेको १४, २१ र २६ दिनपछि उक्त धानका जातहरुमा रोग रेकर्ड गरिएको थियो। सन् २०१० मा रोगका परिवर्त्यहरु (Variables) विभिन्न जातमा बेग्लाबेग्लै रुपमा देखा परे तथा मरेका पातहरु संख्यात्मक रुपमा मात्रै फरक देखिए। अन्य परिवर्त्यहरु (Variables) भने एक अर्का सँग सकारात्मक रुपले अन्तरसम्बन्धित देखिए। परिवर्त्यहरुको सामहिक विश्लेषण गर्दा तीन वटा जातिय समहहरुमा विभाजित रहेको पाईयो, जसमा सावित्रीमा सबैभन्दा कम र Jasmine-85 र Betichikon जातमा सबैभन्दा बढ़ी रोगको परिमाण देखियो । सन् २०११ मा धानका विभिन्न जातहरुमा रोगको अवस्था र रोग लाग्ने संक्रमित क्षेत्र बेग्लाबेग्लै देखिए । सावित्री, MTU-1010 र IR-26 मा कम रोग मापन गरियो । तेतेप र IAC-165 मा क्रमश: सबैभन्दा कम र सबैभन्दा बढ़ रोग ग्रस्त र रोग वद्धी (AUDPC) भएको अवलोकन गरियो। तसर्थ, तेतेप र सावित्री जातलाई वर्णशंकर प्रक्रियाको लागि दात पुर्खाको रुपमा प्रयोग गर्न सकिने, र यिनीहरुको बोटको वनौटलाई आधार मानेर जातिय छनौट गर्दा धानमा पातेफेद डढुवा रोग अवरोध क्षमता सुधार गर्न सकिने निक्यौल गरियो ।

\section{INTRODUCTION}

Sheath blight (ShB) disease caused by fungus Rhizoctonia solani (Kuhn), occurs throughout the rice growing areas in Nepal (Manandhar 1987, Manandhar et al 1992) having high potential threat to rice yield (NARC 1997, Gharti et al 2004). This rice disease can reduce yield up to 28\% (Parajuli 1997) and deteriorate grain quality by breaking grain during milling (NRRP 2000). The fungus has a wide host range, thus known to infect more than 33 plant families of 188 genera (Srinivasachary et al 2011, Sattari et al 2014). This pathogen does not produce spores instead lesion multiplication in a rice canopy occurs through the growth of runner hyphae from mother lesion at surface of rice tissues (leaf sheath), which establish penetration structures to produce new lesion (Ou 1985). Since the disease spread in tillers, therefore requires frequent physical contact among infectious and healthy tiller for intensification (Savary et al 1988). The duration of canopy wetness is another key factor for favoring disease intensification within a tiller and extensification in other tillers or plants (Castilla et al 1996).

Host plant resistance against diseases represents most important key approach for disease management, being pro-poor and environment friendly technology having potentiality to suppress disease epidemics efficiently. In the case of ShB, only quantitative (partial) resistance can be expected in rice due to wide host range of the pathogen (Pinson et al 2005, Srinivasachary et al 2011, Zou et al 2014). Therefore, screening for host plant resistance to rice ShB has been conducted for many years worldwide including International Rice Research Institute (IRRI), where more than 30,000 accessions were tested (Mew et al 2004).

Despite of these efforts, no rice variety with a high level of resistance to ShB is currently deployed in Asia (Crill et al 1981, Shrestha 1996, Srinivasachary et al 2011). In Nepal, some level of resistance against ShB was obtained in some genotypes (NARC 1997, Shrestha and Parajuli 2000, Gharti et al 2004, Yadav et al 2004). Use of synthetic chemicals was reported to minimize disease severity and yield loss (Parajuli 1997, Gharti et al 2004). However, chemicals are not economical and might cause adverse impact on ecological environment. Tulasi- and Neem-based bio-pesticides were screened against the disease with comparable efficacy of Neem-based fungicides over synthetic chemicals. 
Breeding for ShB resistance in rice has been difficult, mainly because of the lack of identified donors in cultivated rice varieties (Bonmann et al 1992, Srinivasachary et al 2011, Liu et al 2013, Zou et al 2014). To date, no variety has been found to be immune to $R$. solani, although cultivars with varying levels of resistance were reported (Khush 1977, Groth and Novick 1992, Zou et al 2000, Shrestha et al 2008, Hossain et al 2014, Zou et al 2014). Resistance to Shb is a complex, quantitative trait controlled by polygenes (Sha and Zhu 1990, Li et al 1995, Pinson et al 2005). The accurate measurement of ShB resistance under field conditions depends on a range of environmental factors (Ou 1985, Castilla et al 1996, Eizenga et al 2002) and plant morphological traits, such as plant height (Li et al 1995, Zou et al 2000, Pinson et al 2005, Eizenga et al 2013, Sattari et al 2014), which interact, resulting in the variation in resistant phenotypes.

Disease intensification and spread are favored by long duration of tissue wetness (Castilla et al 1996), which depends on canopy microclimate. Therefore, morphological attributes of rice genotypes can influence strongly disease intensification and spread, by providing an environment to disease development with varying levels of contact frequency and canopy wetness duration. Morphological traits allowing a reduction of disease epidemics can, thus be associated to disease escape mechanisms (Poland et al 2009, Zou et al 2014). Rice ShB is predominantly canopy-borne in terms of spread, even though the pathogen is often soil-borne (Savary and Mew 1996). The diversity of genotypes in terms of morphological traits and maturity duration are two important factors for the development of sheath blight epidemics. The genetic diversity of rice may incorporate genes that directly contribute to physiological host resistance to ShB (Srinivasachary et al 2011, Zou et al 2014), genes that determine the architecture of crop canopies, as well as genes from these different groups that collectively confer resistance through interactions. Therefore, the objective of the study was to assess the diversity of rice genotypes in terms of susceptibility to sheath blight, according to genetic group and morphological traits under field conditions.

\section{MATERIALS AND METHODS}

The components of physiological resistance to ShB were quantified using the detached tiller test during 2010. The test was undertaken in Plant Pathology Laboratory (PPL) at Regional Agricultural Research Station (RARS), Tarahara, Nepal to minimize the effect of disease escape. Attempt was made to maintain leaf wetness and negate disease spread at the canopy level among the tillers as only one tiller was used. In 2011, an experiment was conducted including 28 entries received from IRRI to evaluate morphological resistance to ShB under field conditions at RARS, Tarahara.

The experimental site is situated in eastern terai region of Nepal at $136 \mathrm{~m}$ above sea level and at $26^{\circ} 42^{\prime} 16.85^{\prime \prime}$ North latitude and $87^{\circ} 16^{\prime} 38.43^{\prime \prime}$ East longitude (Figure 1) The climate of the area is sub-tropical with cool winter $\left(8^{\circ} \mathrm{C}\right)$ and hot summer $\left(37^{\circ} \mathrm{C}\right)$. The research station has six command districts where rice is the number one food crop (RARS 2014). Majority of the area is under irrigation but recently adversely affected by occasional flood and drought. The ShB susceptible varieties such as Sona Masuli, Ranjeet and others are popularly grown and are being infected each year by this pathogen. As a result, inoculums build up in the soil year after year in an alarming way to cause the disease in other recommended varieties.

\section{Plant Materials}

Twelve popular rice varieties among farmers in Nepal susceptible to diseases were used (Table 1). The material consisted of tillers with roots remained attached to the tillers were detached from the selected rice varieties and grown in a screen house. The tiller collection was made at 42 days after transplanting of 14-day old seedlings. The roots were washed under tap water, and each tiller was placed in a test tube filled with $10 \mathrm{ml}$ of distilled water. Seedlings of 28 entries for field trial were raised in dry seedbeds during 2011.

\section{Inoculation Method, Disease Assessment and Experimental Design}

The inoculum consisted of 7-day-old sclerotia, obtained by placing at the centre of each $9.5 \mathrm{~cm}$ diameter petri dish filled with PDA (extract from $200 \mathrm{~g}$ of potato $\mathrm{L}^{-1}, 20 \mathrm{~g} \mathrm{~L}^{-1}$ dextrose, $20 \mathrm{~g} \mathrm{~L}^{-1}$ agar) and incubating at $28^{\circ} \mathrm{C}$ in the darkness. The local isolate, collected at the RARS experimental farm, was used to prepare the inoculum. This isolate, when inoculated on rice, produced typical sheath blight symptoms on sheath and leaves. Mycelial growth and sclerotia production was also typical of $R$. solani. To standardize the inoculum, only sclerotia with a diameter size of $1.5 \pm 0.3 \mathrm{~mm}$ were used. Tillers were inoculated by transferring a single sclerotium just below the leaf collar, on the inner side of the sheath, of the second top-most collar of the tiller, thus corresponding to the second or third leaf of the tiller from the top.

The inoculated tillers were grouped in tube racks. Each group of tillers was sprayed with distilled water and placed into a transparent plastic bag to provide an environment, where air was saturated with humidity and tissue surface was moist. The racks were transferred into a growth chamber at $25^{\circ} \mathrm{C}$, with a $12 \mathrm{~h}$ photoperiod, until disease assessment 7 days after inoculation (DAI).

The following disease variables were measured for each tiller: number of lesions; disease severity; and distance between the tips of the lowest and highest lesions on the sheaths (Vertical Sheath Colonization, VSC). Four independent experiments were performed. Each experiment was arranged according to a randomized complete block design, with three blocks including each of the 12 rice varieties assigned at random. Disease severity and VSC values were arc-sine transformed before analyses of variance. 


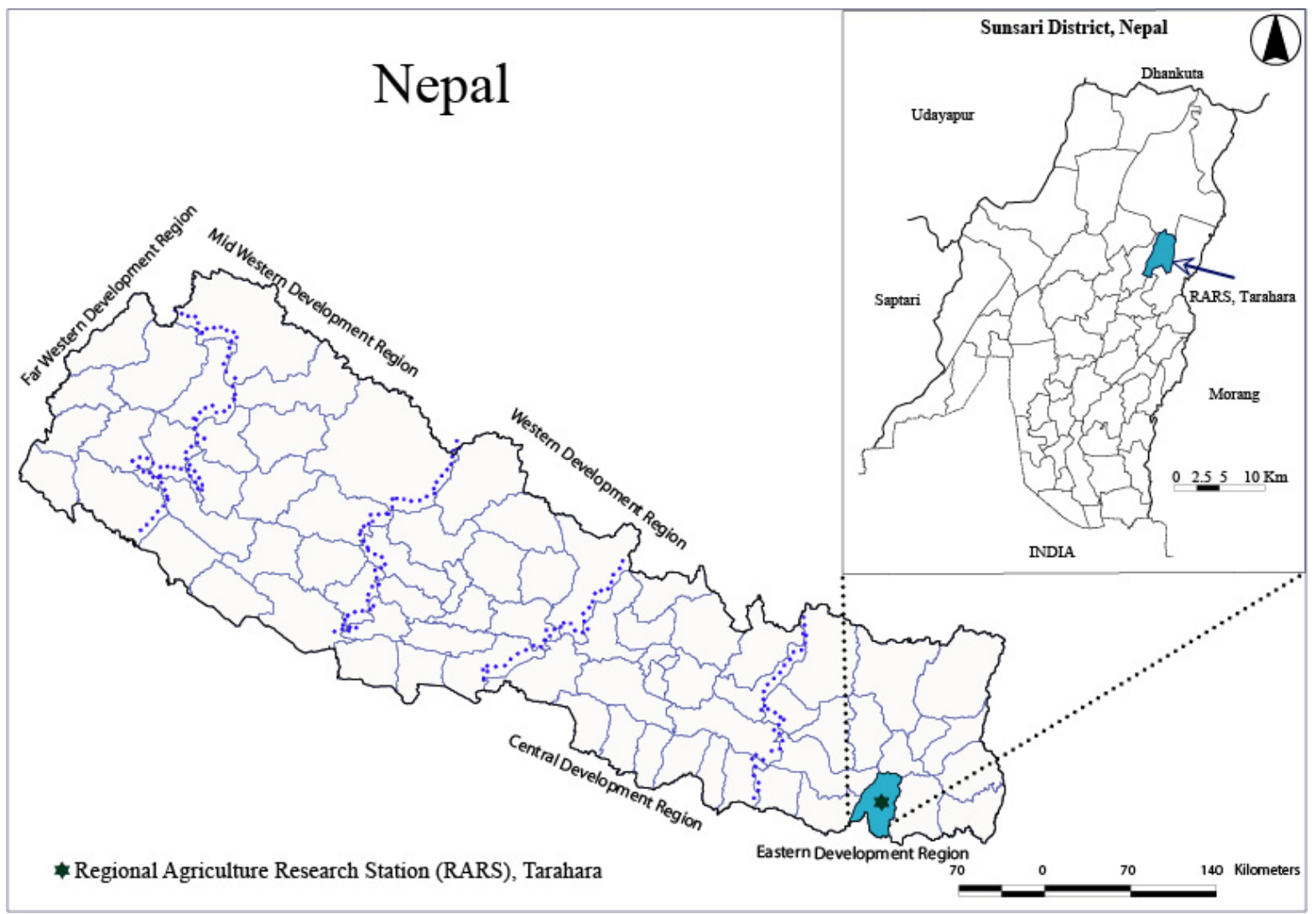

Figure 1. Location of the experimental site in RARS, Tarahara, NepalTable 1. Varieties used in the detached tiller test to measure sheath blight resistance components in rice in 2010.

\begin{tabular}{ll}
\hline $\begin{array}{l}\text { Varieties } \\
\text { Jasmine-85 }\end{array}$ & $\begin{array}{l}\text { Basis of selection } \\
\text { Rudruchi } \\
\text { Khato-chalani } \\
\text { Teqing }\end{array}$ \\
$\begin{array}{l}\text { Reported to be resistant (Zou et al 2000) } \\
\text { Betichickon }\end{array}$ & $\begin{array}{l}\text { Reported to be resistant (Li et al 1995, Pinson et al 2005) } \\
\text { BR-11 }\end{array}$ \\
\hline Rardinath-1 & Reported to be resistant (Shrestha et al 2008) \\
Sabitri & Varieties popularly grown in a larger areas in Nepal \\
Radha-12 & \\
Radha-4 & \\
Kanchhi Masuli & \\
Anandi & \\
\hline
\end{tabular}

The field trial was laid out according to randomized complete block design with three replications. Two rows of each entry were transplanted when seedlings were 25 day old. Five hills per row spaced at $15 \mathrm{~cm}$ plant to plant and $20 \mathrm{~cm}$ row to row, the middle hill was planted with susceptible genotype i.e Swarna (source hill) and either side of the source hill was planted with two hills of the entry. Each entry was surrounded by the buffer hills i.e. Sabitri, a variety with physiological resistance to sheath blight (Gharti et al 2004). The trial block was fertilized with 100:50:0 $\left(\mathrm{N}_{2} \mathrm{P}_{2} \mathrm{O}_{5}: \mathrm{K}_{2} \mathrm{O}\right) \mathrm{kg} \mathrm{ha}^{-1}$. Water level of $5 \mathrm{~cm}$ was maintained from 10 days after transplanting to grain filling stage. Weed management was done manually before top dressing.

For field experiment, the sclerotium with a small piece of PDA was inoculated to sterilized rice stem beats kept in a conical flask to prepare inoculum. The flasks were incubated at $25 \pm 2{ }^{0} \mathrm{C}$ until the beats were colonized with fungal mycelium. Fifty six day old source hill was inoculated with 3-5 pieces of $R$. solani colonized rice stem beats, inserting them in the middle of the hill just above the water surface (IRRI 1992). Natural spread of the disease was allowed to the either side of the source hill.

Disease scoring was begun from 14 days after inoculation and continued for three times at weekly interval. At first scoring, only four hills, one side of the source hill was considered. Total number of tillers and infected tillers were counted to calculate disease incidence. On the second date, the remaining four hills were scored. During the final third date, total hills of the entry were scored. Area under disease progress curve (AUDPC) was calculated using the formula outlined by Shanner and Finney (1977) to estimate the horizontal disease spread among the tillers as follows: 
$A U D P C=\sum_{i=1}^{n}\left[\frac{\left(\mathrm{y}_{\mathrm{i}+1}+\mathrm{y}_{\mathrm{i}}\right)}{2}\right] \times\left(x_{i+1}+x_{i}\right)$

Where,

$$
y_{i}=\text { disease severity at the } i^{\text {th }} \text { observation, } x_{i}=\text { time at the } i^{\text {th }} \text { observation, and } \mathrm{n}=\text { total number of observations }
$$

Data of the detached tiller test and field trial was analyzed using MSTATC. Means were separated to compare the effect of genotypes, experiment and their interaction on disease variables.

\section{RESULTS}

\section{Relationships between Disease Variables}

The different variables measured were significantly $(P<0.01)$ correlated (Table 2$)$, with correlation coefficients above 0.8 for the variable pairs (number of lesions tiller ${ }^{-1}$ and disease severity), (number of lesions tiller ${ }^{-1}$ and VSC) and (disease severity and VSC).

Figure 2A showed the ranking of varieties according to increasing number of lesions tiller ${ }^{-1}$. The same ranking of varieties was used to display the other disease variables (Figure 2B and C). The number of lesions tiller ${ }^{-1}$ ranged between 3.8 and 8.9. Sabitri and Betichikon had the lowest and highest number of lesions tiller ${ }^{-1}$, respectively. Anandi and Kanchhi Masuli had the next lowest number of lesions (4.9). The number of lesions progressively increased from 5.2 to 8.9 among the 8 other varieties. Jasmine 85 had more than 8 lesions tiller $^{-1}$. Disease severity (and the corresponding LSD) ranged from 6.07\% (Sabitri) to 24.13\% (Jasmine 85; Figure 2B).
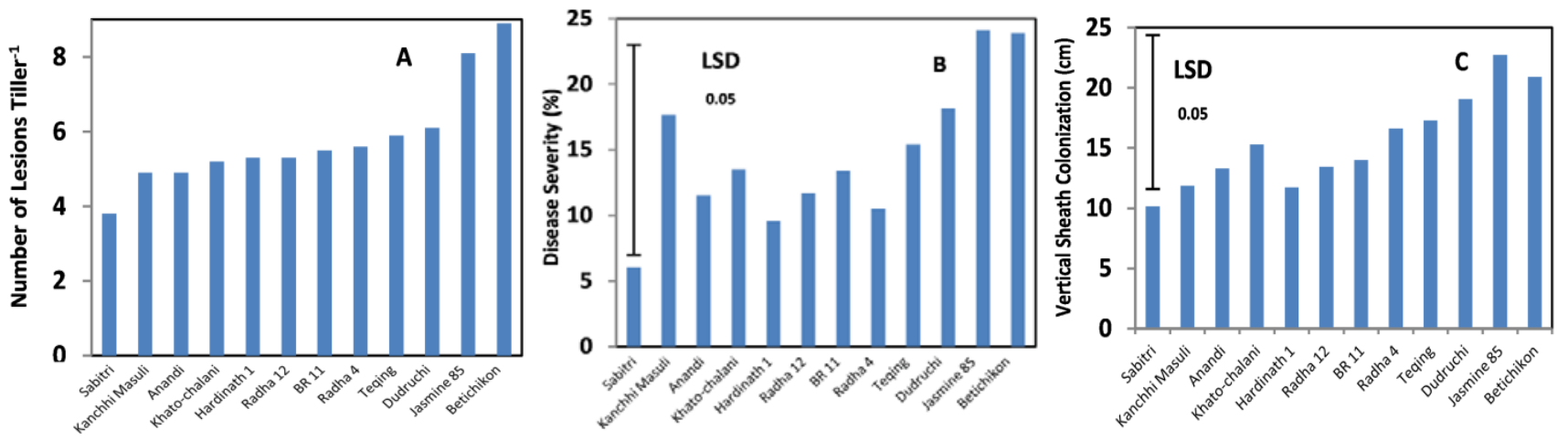

Figure 2. SBD variables measured on 12 rice varieties. Each bar represents for a disease variable of a given variety. A: number of lesions; B: disease severity; C: vertical sheath colonization (VSC).

\section{Effect of Varieties on Sheath Blight Variables}

The varieties Hardinath 1 , Radha 4 variety had the largest effect on the disease severity $(P=0.004)$, and vertical sheath colonization $(P$ $=0.03)$. Experiments had no effect on all variables. The interaction of variety $\times$ experiment was not significant, and was associated with $P$ values larger than 0.34 for all variables except for the disease severity for which $P$ value was 0.01 .

Anandi, Radha 12, BR 11 and Khato-chalani formed one group with a disease severity lower than 14\%. Betichikon had the next highest disease severity (23.9\%) followed by Dudruchi (18.14\%), Kanchhi Masuli (17.68\%) and Teqing (15.39\%). The ranking of varieties was in general similar with respect to VSC (Figure 2C). VSC was highest for Jasmine $85(22.74 \mathrm{~cm})$. Sabitri and Hardinath-1 showed the lowest values for both disease severity and VSC variables.

When considering the different disease variables measured (Figure 2), Sabitri consistently had the first lowest values. Hardinath-1 was among the varieties with lowest disease severity and VSC next to Sabitri, but had intermediate values for number of lesions. Kanchhi Masuli had medium-high levels of disease severity, but showed lower values for number of lesions and VSC. Anandi had the second lowest values for number of lesions, but had intermediate values for disease severity and VSC. Betichikon was the most susceptible in terms of number of lesions, and was also the second most susceptible variety next to Jasmine 85 with regard to disease severity and VSC. Dudruchi and Teqing had medium-high levels lesions, disease severity and VSC. Khato-chalani, BR 11 and Radha 12 were varieties with medium levels of number of lesions, disease severity and VSC. Radha 4 was less susceptible with respect to disease severity, but had medium-high levels of number of lesions and VSC. 
Table 2. Correlation coefficients among the different rice sheath blight disease variables measured at 7 days after inoculation on detached tillers in 2010.

\begin{tabular}{llll}
\hline Disease variables & Number of lesions tiller ${ }^{-1}$ & Disease severity (\%) & Vertical sheath colonization (VSC, $\mathbf{c m})$ \\
\hline Number of lesions tiller $^{-1}$ & & 0.88 & 0.90 \\
Disease severity (\%) & & 0.83 \\
\hline
\end{tabular}

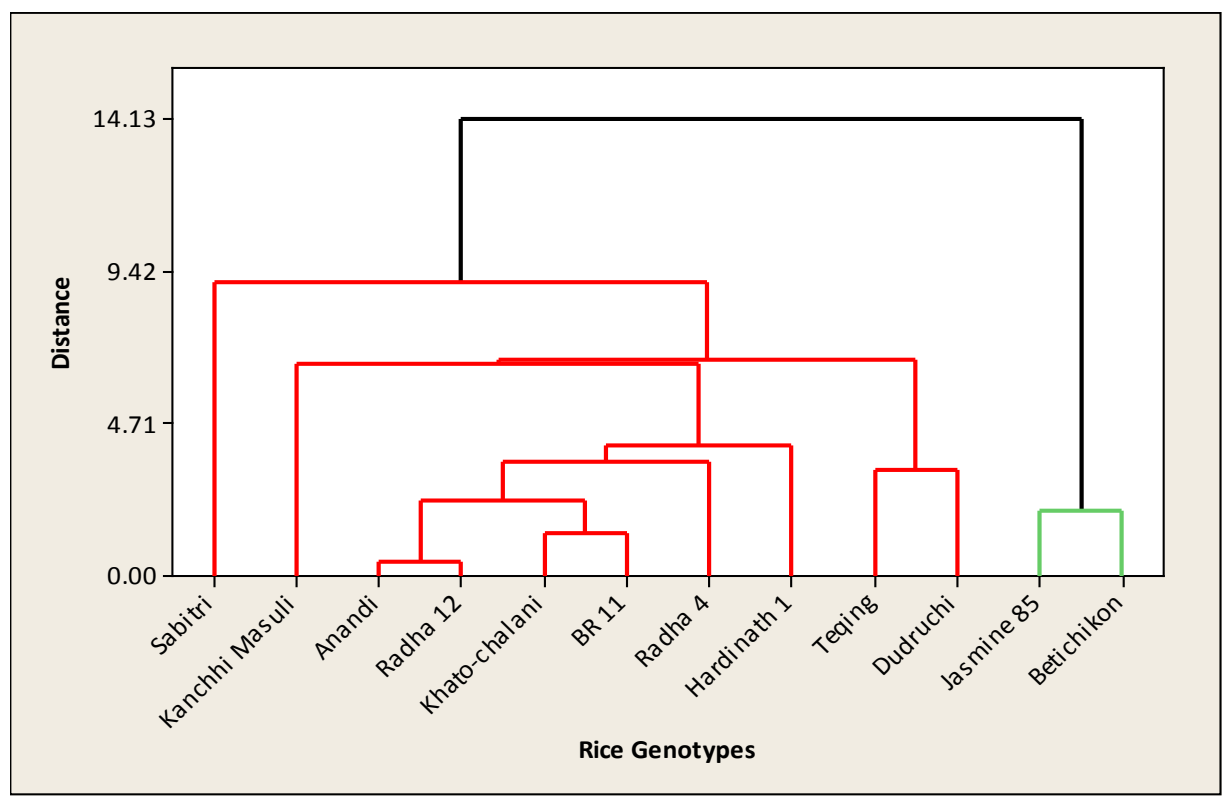

Figure 3. Clusters of rice varites based on SBD variables measures after inoculation on detached tillers. Clusters were generated from hierarchial clustering analysis using the Euclidian distance of 12 rice varieties according to number of leasions, disease severity and vertical sheath colonization (VSC) in 2010.

\section{Variety Groups According to the Components of Resistance}

Cluster analysis was conducted with three variables: number of lesions, disease severity, and VSC. The three variables captured the main components of resistance measured, with respect to physiological resistance. Three main groups were identified from the hierarchical cluster analyses: a first group with Sabitri, a second with Jasmine-85 and Betichikon, and the third, larger group, including all the other varieties (Figure 3). The first group corresponded to lowest average values in number of lesions (3.8), disease severity $(6.07 \%)$ and VSC $(10.16 \mathrm{~cm})$. The second group had the highest average number of lesions, highest disease severity and maximum values for VSC.

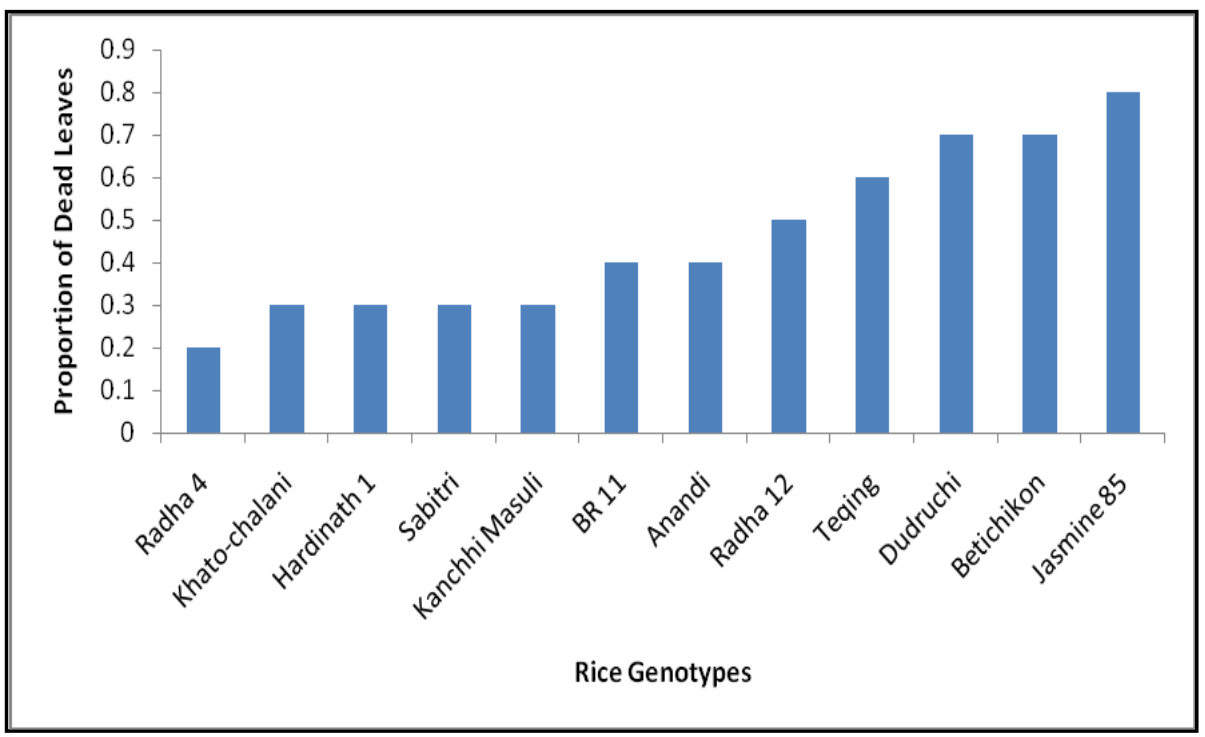

Figure 4. Proportion of dead leaves for 12 rice varities, 7 days after inculation by $R$. solani on detached tillers. 


\section{Effect of Variety on Leaf Blade Senescence and Occurrence of Dark Margin}

Proportion of dead leaves at 7 DAI ranged from 0.20 (Radha-4) to 0.80 (Jasmine-85; Figure 4). The next lowest values were observed for Hardinath-1, Khato-chalani, Sabitri and Kanchhi Masuli (0.30), and BR-11 and Anandi (0.40). The highest proportion of dead leaves was observed for Betichikon and Dudruchi (0.70).

\section{Field Screening 2011}

During 2011, genotypes differed significantly $(P=0.05)$ for the final disease development and AUDPC values (Table 3). The disease incidence varied from 13 to 90\%, while AUDPC values ranged from 46 to 515 among the genotypes. Out of 28 genotypes, seven showed moderate level of resistance to sheath blight. Among them Tetep showed the lowest disease incidence and AUDPC values. The genotype did not show diseases during the first and second scoring. The genotypes having $>56 \%$ disease incidence and $>303$ AUDPC values were categorized as susceptible ones. Among them, Kammara recorded highest final disease incidence (90\%), while IAC 165 had the highest AUDPC values (515).

Disease spread in moderately resistant (MR) genotypes was slower than others. Over two weeks after inoculation, increase in disease incidence was up to $17.7 \%$ and AUDPC value was recorded below 100 in such genotypes. On the contrary, disease spread was faster in susceptible genotypes. Two weeks after inoculation, susceptible lines attained up to $90 \%$ disease incidence with the highest AUDPC value of 515 .

N22 (IRGC-19379) and Tomoe Moch had statistically similar disease incidence with MR genotypes, but were put under susceptible group based on higher AUDPC values, which indicated that these lines might record higher disease incidence over time beyond 28 DAI. Tetep had the lowest values for disease incidence (13.3) and AUDPC (46.6). The genotypes Sabitri, IR-26, SHB-134-11-23, MTU-1010 were also less susceptible based on these variables (Table 3).

\section{DISCUSSION}

A range of complementary variables were used to describe the disease cycle. The number of lesions was used to quantify the infection efficiency of the pathogen, i.e., its capacity to infect the host tissue and produce lesions. VSC was the most discriminating variable, and showed consistent results, as no significant experiment $\times$ variety interaction was detected (Figure 2C). Significant $(P=0.03)$ effect of variety on VSC was detected from the present experiments. The VSC represents key component of resistance, reflecting the capacity of the pathogen to progress and the lesion to expand. It should, therefore be measured when comparing rice varieties, because differences may be detected, and contribute to identifying overall differences in resistance level.

Disease severity is also an important variable to measure ShB resistance in rice. The variable was substantaily different among the varieties, and thus reflected different mechanisms of partial resistance in rice. Disease severity and VSC variables provided an insight on the ability of runner hyphae of the fungus to progress spatially over plant tissues

Many varieties were ranked differently, according to the disease variable measured (Figure 2). For example, Kanchhi Masuli had medium-high values for the number of lesions, whereas it was associated with low and intermediate values for the other disease variables. Differential response according to components of resistance has been reported for many other diseases, such as barley leaf rust, wheat leaf rust, groundnut rust, and potato late blight (Parlevliet 1979, Savary et al 1988). In the same way, the study indicates that several components of resistance need to be measured in order to provide an overall assessment of the level of resistance to sheath blight.

The most resistant variety from the present study, Sabitri, was reported to have a relatively high level of resistance (Gharti et al 2004). Jasmine-85 (Srinivasachary et al 2011) and Betichikon (Shrestha et al 2008) were reported to have higher level of resistance to sheath blight, but had high levels of disease intensity with respect to the number of lesions per tiller, disease severity and VSC. Betichikon was also reported to be susceptible with respect to physiological resistance (Willocquet et al 2011). Dudruchi also showed medium-high level of susceptibility to ShB, whereas it was also known for relatively higher level of ShB resistance (Shrestha et al 2008). Teqing and Khato-chalani, which are considered as varieties with high levels of partial resistance, were in general, associated to intermediate to medium levels of disease intensity in the study, which may indicate a larger tolerance to the disease (Zadoks et al 1979).

In general, difference between results in present work and other studies may have several such as differences in methods and types of disease variables measured, which are associated with differences in resistance mechanisms expressed. For example, the expression of some defense mechanisms may be higher in the case of the detached tiller tests than in the tests performed with detached leaves (eg, IRRI 1987, Prasad and Eizenga 2008), corresponding to plant organs which are surviving in isolation of other tiller and root tissues. Another example is comparison of tests performed in the field (eg, Li et al 1995, Pinson et al 2005) with detached tiller: the former type of test includes the combined effects of physiological resistance and disease escape, while the second type of test focuses on physiological resistance. A third, intermediate example, corresponds to the micro-chamber tests (Jia et al 2007), which are performed at the plant scale at a very early stage, and partly incorporates a fair level of disease escape mechanisms (associated with plant height and contact between tillers), as compared to the detached tiller test.

Considering results from detached tiller test and field screening, Sabitri, earlier reported to be resistant to blast (Chaudhary 1999) and bacterial blight (Adhikari 2004), confers higher level of physiological and morphological resistance to ShB. Tetep is the most resistant to ShB in the field screening. Morphological resistance (disease escape) in rice may vary over locations, seasons and genotypes; and a variety with physiological resistance may show susceptibility in the field conditions (Srinivasachary et al 2011, Zou et al 2014). Sabitri is a medium-tall variety and its tillers are up-right straight with minimum angle among themselves. Its leaves form minimum angle with 
tillers allowing penetration of sunlight and good aeration. The flag leaves are straight up-right with length of more than $20 \mathrm{~cm}$ above panicles. These morphological characters allow less contact among tillers, thus negate disease spread. This is probably the reason that Sabitri and Tetep were extensively used as donor parents in breeding program considering plant morphology as a model in selecting the genotypes with similar plant stature for improving ShB resistance in rice.

Table 3. Resistance in rice genotypes to sheath blight under field conditions in 2011 wet season

\begin{tabular}{|c|c|c|c|c|c|}
\hline \multirow[t]{2}{*}{ IRRI accession } & \multirow[t]{2}{*}{ Genotype } & \multicolumn{3}{|c|}{ Disease incidence (\%) } & \multirow[t]{2}{*}{ AUDPC $^{\ddagger}$} \\
\hline & & 14 DAI & 21 DAI & $28 \mathrm{DAI}^{\dagger}$ & \\
\hline IRGC-32576 & TETEP & 0 & 0 & $13.33 \mathrm{G}$ & $46.66 \mathrm{H}$ \\
\hline IEGC-24154 & IR 26 & 0 & 0 & 16.13 FG & $56.45 \mathrm{GH}$ \\
\hline IR86174-17-15-11-23 & SHB-134-11-23 & 0 & 1.852 & 19.16 FG & 80.04 F-H \\
\hline MTU-1010 & MTU-1010 & 1.852 & 1.515 & $20.69 \mathrm{FG}$ & $89.50 \mathrm{E}-\mathrm{H}$ \\
\hline IRGC-39723 & RNR 57979 & 0.952 & 5.119 & 16.07 FG & $95.40 \mathrm{D}-\mathrm{H}$ \\
\hline IR86174-17-5-18-45 & SHB-129-18-45 & 1.667 & 4.227 & $17.72 \mathrm{FG}$ & 97.46 D-H \\
\hline IRGC5565 & SABITRI & 1.389 & 4.568 & $17.56 \mathrm{FG}$ & 98.31 D-H \\
\hline IRGC-39932 & SI 51 & 2.279 & 3.262 & $21.98 \mathrm{E}-\mathrm{G}$ & 107.8 C-H \\
\hline IRGC-19907 & IR 24 & 0 & 5.681 & $20.39 \mathrm{FG}$ & 111.1 C-H \\
\hline IR86174-17-15-11-44 & HSB-134-11-44 & 0 & 6.277 & $20.07 \mathrm{FG}$ & 114.2 C-H \\
\hline IR86174-17-15-11-42 & SHB-134-11-42 & 3.03 & 8.73 & $12.73 \mathrm{G}$ & 116.3 C-H \\
\hline IRGC-77301 & & 2.646 & 4.884 & 22.66 E-G & $122.8 \mathrm{C}-\mathrm{H}$ \\
\hline RTP11793 & RNP74229 & 0.813 & 6.389 & 22.29 E-G & 125.6 C-H \\
\hline IRGC-38624 & BR 3 & 2.464 & 7.898 & $21.48 \mathrm{E}-\mathrm{G}$ & 139.1 C-H \\
\hline IRGC-40020 & LANKANDA 41 & 3.171 & 6.624 & 24.89 C-G & 144.6 B-H \\
\hline IRGC-47111 & RAJESHWARI & 0 & 5.808 & 33.09 B-G & 156.5 B-H \\
\hline IRGC-117278 & SWARNA & 1.235 & 10.345 & $23.72 \mathrm{D}-\mathrm{G}$ & 159.7 B-H \\
\hline IRGC-59244 & TARA & 1.235 & 11.765 & 28.37 B-G & 186.0 B-H \\
\hline IRGC-53200 & MATAHAMBRE & 3.889 & 13.041 & $40.52 \mathrm{~B}-\mathrm{G}$ & 246.7 B-H \\
\hline IRGC-6264 & $\mathrm{N}-22$ & 1.389 & 16.186 & $41.86 \mathrm{~B}-\mathrm{G}$ & 264.7 B-G \\
\hline IRGC77471 & YUEFU & 5.635 & 15.588 & $40.92 \mathrm{~B}-\mathrm{G}$ & $272.1 \mathrm{~B}-\mathrm{F}$ \\
\hline IRGC116438 & $\mathrm{AZ}(\mathrm{C})$ & 0 & 16.667 & 44.74 B-G & 273.3 B-F \\
\hline IRGC-117398 & VANDANA & 2.564 & 9.804 & 63.09 A-D & 298.4 B-E \\
\hline IRGC-4819 & $\mathrm{N}-22$ & 4.312 & 9.283 & $63.72 \mathrm{~A}-\mathrm{C}$ & 303.1 B-D \\
\hline IRGC-74540 & TOMOE MOCH & 3.935 & 11.997 & 61.11 A-E & $311.6 \mathrm{BC}$ \\
\hline IRGC-19379 & N 22 & 0 & 16.987 & $56.02 \mathrm{~A}-\mathrm{F}$ & $315.0 \mathrm{BC}$ \\
\hline IRGC-62172 & KAMMRA & 0 & 4.762 & $90.20 \mathrm{~A}$ & $349.0 \mathrm{AB}$ \\
\hline IRGC82775 & IAC 165 & 6.278 & 36.84 & $67.42 \mathrm{AB}$ & $515.8 \mathrm{~A}$ \\
\hline LSD $_{0.05}$ & & NS & NS & 33.47 & 172.3 \\
\hline
\end{tabular}

${ }^{\dagger}$ Values followed by different letters are significantly different at $(\mathrm{P}=0.05)$

${ }^{\ddagger}$ Values followed by different letters within the column are significantly different at $(\mathrm{P}=0.05)$

\section{ACKNOWLEDGEMENTS}

The works were financially supported by International Rice Research Institute, Philippines through Cereal System Initiative for South Asia (CSISA). The author is thankful to Nepal Agricultural Research Council for facilities to conduct field studies. The author highly acknowledges assistance from Mr Nabin Kumar Dangal, Ms Sarita Manandhar, Mr Rudra Bhattarai, Mr Sudeep Kumar Upadhyay, Mr Shukra Raj Shrestha, Mr Surya Adhikari, and Ms Parbati Joshi for conduction of experiment and data management.

\section{REFERENCES}

Adhikari TB and TW Mew. 1994. Resistance of rice to Xanthomonas oryzae pv. oryzae in Nepal. Plant Dis. 78:64-67.

Bonmann JM, GS Kush and RJ Nelson. 1992. Breeding for resistance to pests. Annu. Rev. Phytopathol. 30:507-523.

Castilla NP, RM Leano, FA Elazegui, PS Teng and S Savary. 1996. Effects of plant contact, inoculation pattern, leaf wetness regime, and nitrogen supply on inoculum efficiency in rice sheath blight. J. Phytopathol. 144:187-192.

Chaudhary B. 1999. Effect of blast disease on rice yield. Nepal Agriculture Research Journal 3:8-13.

Crill P, FL Nuque, BA Estrada and JM Bandong. 1982. The role of varietal resistance in disease management. In: Evolution of gene rotation concept for rice blast control. IRRI, Los Banos. Pp.103-121.

Eizenga GC, B Prasad, AK Jackson and MH Jia. 2013. Identification of rice sheath blight and blast quantitative trait loci in two different O. sativa/O. nivara advanced backcross populations. Molecular Breeding 31:889-907.

Eizenga GC, FN Lee and JN Rutger. 2002. Screening of Oryza species plants for rice sheath blight. Plant Dis. 68:808-812.

Gharti DB, JB Sah, CL Shrestha and BR Khadge. 2004. Status of sheath blight disease of rice in central terai of Nepal. Paper presented in the 24th National Summer Crops Workshop, Lalitpur, 28-30 June, 2004.

Groth DE and EM Novick. 1992. Selection for resistance to sheath blight through the number of infection cushions and lesion type. Plant Dis. 76:721-723.

Hossain MK, OS Tze, K Nadarajah, K Jena, MAR Bhuiyan and W Ratnam. 2014. Identification and validation of sheath blight resistance in rice (Oryza sativa L.) cultivars against Rhizoctonia solani. Canadian Journal of Plant Pathology 36(4):482-490.

IRRI. 1987. Annual report for 1987. International Rice Research Institute, Los Baños, Philippines.

IRRI. 1992. Annual report. 1992. International Rice Research Institute, Los Baños, Philippines. 
Jia Y, F Correa-Victoria, A McClung, L Zhu, G Liu, Y Wamishe, J Xie, MA Marchetti, SRM Pinson, JN Rutger and JC Correll. 2007. Rapid determination of rice cultivar responses to the sheath blight pathogen Rhizoctonia solani using a micro-chamber screening method. Plant Dis 91:485-489.

Khush GS. 1977. Disease and insect resistance in rice. Adv. Agron. 29:268-341.

Li ZK, SRM Pinson, MA Marchetti, JW Stansel and WD Park. 1995. Characterization of quantitative trait loci (QTLs) in cultivated rice contributing to field resistance to sheath blight (Rhizoctonia solani). Theor. Appl. Genet. 91:382-388.

Liu G, Y Jia, A McClung, JH Oard, FN Lee and JC Correl. 2013. Confirming QTLs and finding additional loci responsible for resistance to rice sheath blight disease. Plant Disease 97:113-117.

Manandhar HK, K Shrestha and P Amatya. 1992. Seed-borne fungal diseases. In: Plant Disease, Seed Production and Seed Health testing in Nepal (SB Mathur, P Amatya, K Shrestha and HK Shrestha, eds). Proceedings of the first HMG/DANIDA/FAO training course in seed health testing techniques. Pp.59-74.

Manandhar HK. 1987. Rice disease in Nepal. Plant Pathology Division Khumaltar, Department of Agriculture /HMG Nepal and Winrock International USAID.

Mew TW, S Savary, CM Vera Cruz, and JE Leach. 2004. Looking ahead in rice disease research and management. Crit. Rev. Plant Sci. 23:103-127.

NARC. 1997. 25 years of Rice Research in Nepal (1972-1997). Nepal Agricultural Research Council, National Rice Research Program, Nepal.

NP Castilla, FA Elazegui, CG McLaren, MA Ynalvez and PS Teng. 1995. Direct and indirect effects of nitrogen supply and disease source structure on rice sheath blight spread. Phytopathology 85:959-965.

NRRP. 2000. Annual Report. 1999/2000. National Rice Research Program, Hardinath.

Ou SH. 1985. Rice Diseases, 2nd ed. Commonwealth Mycological Institute, Surrey, England.

Parajuli GP. 1997. Efficacy of fungicides in controlling neck blast and sheath blight diseases of rice. In: Proceedings of the 18th Summer Crops Workshop. Nepal Agricultural Research Council, National Rice Research Program, Parwanipur. Pp.208-210.

Parlevliet JE. 1979. Components of resistance that reduce the rate of epidemic development. Annu. Rev. Phytopathol. 17:203-222.

Pinson SRM, FM Capdevielle and JH Oard. 2005. Confirming QTLs and finding additional loci conditioning sheath blight resistance in rice using recombinant inbred lines. Crop Sci. 45:503-510.

Poland JA, PJ Balint-Kurti, RJ Wisser, RC Pratt and RJ Nelson. 2009. Shades of gray: the world of quantitative disease resistance. Trends Plant Sci. 14:21-29.

Prasad B and GC Eizenga. 2008. Rice sheath blight disease resistance identified in Oryza spp. accessions. Plant Dis. 92:1503-1509.

RARS. 2014. Annual Report. Regional Agricultural Research Station, Tarahara, Sunsari, Nepal, NARC Publication Serial Number: 00153-63/2014/2015.

Sattari A, B Fakheri, M Noroozi and KM Gudarrzi. 2014. Review: Breeding for resistance to sheath blight in rice. International Journal of Farming and Allied Sciences 3(9):970-979.

Savary S, JP Bosc, M Noirot and JC Zadoks. 1988. Peanut rust in West Africa: a new component in a multiple pathosystem. Plant Dis. 72:1001-1009.

Savary S and TW Mew. 1996. Analyzing crop losses due to Rhizoctonia solani: rice sheath blight, a case study. In: Savary S, Rhizoctonia species: taxonomy, molecular biology, ecology, pathology and disease control (B Sneh, S Jabaji-Hare, S Neate and G Dijst, eds). Kluwer, Dordrecht. Pp.237-24

Sha XY and LH Zhu. 1990. Resistance of some rice varieties to sheath blight. Int. Rice Res. Newsl. 15:7-8

Shanner G and RE Finney. 1977. The effect of nitrogen fertilization on expression of slow-mildewing resistance in Knox wheat. Phytopathology 76:1051-1056.

Shrestha CL and GP Parajuli. 2000. Evaluation of resistance of Rice genotypes against sheath blight 2000. In: Proceeding of 22nd National Summer Crops Research Workshop. National Rice Research Program Hardinath, Nepal. Pp.229-235.

Shrestha CL, I Oña, S Muthukrishnan and TW Mew. 2008. Chitinase levels in rice cultivars correlate with resistance to the sheath blight pathogen Rhizoctonia solani. Eur. J. Plant Pathol. 120:69-77.

Shrestha CL. 1996. Chitinase activity of rice in relation to infection by Rhizoctonia solani Kuhn. Ph. D. Thesis, University of the Philippines, Los Banos, Philippines. .

Srinivasachary S, L Willocquet and S Savary. 2011. Resistance to rice sheath blight - current status and perspectives. Euphytica 178:122.

Willocquet L, JS Lore, S Srinivasachary and S Savary. 2011. Quantification of the components of resistance to rice sheath blight using a detached tiller test under controlled conditions. Plant Dis. 95:1507-1515.

Yadav M, B Chaudhary, CL Shrestha, DK Chaudhary, RB Yadaw and T Akhtar. 2004. Evaluation of rice genotypes for resistance to sheath blight disease. Paper presented in the 24th National Summer Crops Workshop, Khumaltar, Lalitpur, $28-30$ Jun 2004.

Zadoks, J. C., and Schein, R. D. 1979. Epidemiology and Plant Disease Management. Oxford University Press, Oxford, UK.

Zou JH, XB Pan, ZX Chen, JY Xu, JF Lu, WX Zhai and LH Zhu. 2000. Mapping quantitative trait loci controlling sheath blight resistance in two rice cultivars. Theor. Appl. Genet. 101:569-573.

Zou SM, YF Zhang, ZX Chen, W Jiang, MH Feng and XB Pan. 2014. Improvement of rice resistance to sheath blight by pyramiding QTLs conditioning disease resistance and tiller angle. Rice Science 21(6):318-326. 